\title{
ÖZGÜRLÜK YOLU: BANDUNG KONFERANSI VE JAPONYA
}

\author{
Emine SİCIM KAPLAN*
}

\begin{abstract}
$\ddot{\mathbf{O z}}$
II. Dünya Savaşı'nın sona ermesi ve Japonya'nın bu savaşta yenilmesi, Güneydoğu Asya ulusları için dönüm noktasıdır. Yıllarca sömürge altında yaşayan ülkelerin özgürlük mücadeleleri, yeni bir dönemin başladığının göstergesi olmuştur. Bağımsızlıklarını yeni elde eden ülkeler, ortak hedefleri doğrultusunda yakın ilişkiler kurmanın önemini idrak etmişler, bu doğrultuda konferans düzenlemeye karar vermişlerdir. 1955 yılının Nisan ayında Asya, Afrika ve Orta Doğu gibi bölgelerden çeşitli ülkelerin katılımıyla Asya - Afrika toplantısı olarak da bilinen Bandung Konferansı'nı gerçekleştirmişlerdir. Batılı ülkelerin katılmadığ özelliğine sahip Bandung Konferansı'nda, sömürgeciliğe karşı çıkılarak bağımsızlık, karşılıklı dayanışma, dünya barışı vb. konular üzerinde durulmuştur. Geçmişteki yayılmacı ve sömürgeci politikalarına rağmen konferansa Japonya da katılmıştır. Ancak Japonya'nın konferansa davet edilmesi başlangıçta sorun teşkil etmiş, Hindistan Başbakanı Jawaharlal Nehru Asya ülkeleriyle olan sorunlarından dolayı Japonya'nın davet edilmesine karşı çıkmıştır. Bu çalışmada genel hatlarıyla Bandung Konferansı ele alınacak, Amerikan işgalinden sonra barışçıl bir politika benimseyen Japonya'nın, Bandung Konferansı'na giden süreci ve konferanstaki rolünün ne olduğu ortaya konmaya çalışılacaktır.
\end{abstract}

Anahtar Kelimeler: Bandung Konferansı, Japonya, Jawaharlal Nehru, Güneydoğu Asya.

\section{Abstract \\ The Way of Freedom: Bandung Conference and Japan}

The end of the Second World War and the defeat of Japan in this war is a turning point for the nations of Southeast Asia. The struggle for freedom of the countries, which had been colonized for years, demonstrated that a new era has begun. The countries, which newly gained independence, have been realized the importance of establishing close relations in line with their common goals. So that they decided to organize a conference. In April 1955, they held the Bandung Conference, also known as the Asia - Africa meeting, with the participation of various countries from regions such as Asia, Africa and the Middle East. In the Bandung Conference, that was the first international

\footnotetext{
* Arş. Gör. Dr., Selçuk Üniversitesi, Edebiyat Fakültesi, Japon Dili ve Edebiyatı Bölümü, Konya.

E-posta: eminesicim09@gmail.com. ORCID: 0000-0002-9328-1192

(Makale Gönderim Tarihi: 29.04.2021 - Makale Kabul Tarihi: 02.11.2021)
} 
conference without the participation of any Western colonial power, have been discussed about anticolonial, independence, mutual solidarity and world peace. Japan also attended the conference despite its expansionist and colonial policies of the ancient times. However, the invitation of Japan to the conference was a problem at the beginning, Indian Prime Minister Jawaharlal Nehru opposed the invitation of Japan due to its past problems with Asian countries. In this study, the Bandung Conference will be discussed in general terms. Also, the process of Japan to the Bandung Conference and its role in the conference will be revealed.

Key Words: The Bandung Conference, Japan, Jawaharlal Nehru, Southeast Asia.

\section{GİRIŞ}

II. Dünya Savaşı'nın sona ermesi, Güneydoğu Asya için yeni bir savaşın başlangıcı olmuştur. Japonya'nın 1945 yılındaki yenilgisi Asya'da güç boşluğu oluşmasına neden olmuş, bölge için karışıklık ve değişsim yılları başlamıştır. Sahneye bu kez özgürlük isteyen Asyalı uluslar çıkmış, özellikle tekrar sömürge altına girmek istemediklerinden Güneydoğu Asya' da bağımsızlık mücadelesi başlamıştır. 1945 yılının 17 Ağustos tarihinde Sukarno (1901-1970) ve Mohammed Hatta (1902-1980) Endonezya'nın, aynı yılın 2 Eylülü'nde de Ho Chi Minh Vietnam'ın bağımsızlığını ilan etmişlerdir. Ancak her iki ülke de eski sömürge devletleri olan Fransa ve Hollanda'nın bağımsızlıklarını kabul etmemesi sorunuyla karşı karşıya kalmışlardır. Bunun sonucunda Vietnam ile Fransa arasında I. Hindiçin Savaşı; Endonezya ile Hollanda güçleri arasında da bağımsızlık savaşı patlak vermiştir. Bu arada da 4 Temmuz 1946'da Filipinler; 1947 yılında Hindistan ve Pakistan; 4 Ocak 1948'de de Burma bağımsızlıklarını ilan etmişlerdir. ${ }^{1}$ Endonezya'nın Hollanda karşısındaki mücadelesi 1949 yılının sonuna kadar devam etmiş ve Hollanda, 2 Kasım 1949'da Endonezya ile antlaşma imzalayarak, ülkenin bağımsızlığını resmi olarak tanımak zorunda kalmıştır. Aynı şekilde Vietnam ile Fransa arasındaki savaştan Vietnam galibiyetle ayrılmış, 1954 yılındaki Cenevre Antlaşmasıyla Vietnam, Kuzey ve Güney olmak üzere ikiye bölünmüştür. ${ }^{2}$

Güneydoğu Asya bölgesindeki ülkeler özgürlük savaşı verirken, Japonya ise 1945 yılından itibaren yaklaşık yedi yıl sürecek olan Amerikan işgali altına girmiştir. Bu süre zarfında Asya' da komünizm hızla yayılmaya başlamış, 1950-53 yılları arasında da Kore Savaşı yaşanmıştır. Bunun üzerine Amerika, Asya'daki komünist hareketlerin artmasını engellemek amacıyla 1952 yılında Japonya'daki işgaline son vermiştir. Japonya, Amerikan işgalinden kurtulduktan sonra tıpkı II. Dünya Savaşı'nda olduğu gibi hammadde ve pazar arayışı için yeniden Güneydoğu Asya'ya dönmeye çalışmıştır. Bölgeye yönelmesindeki en önemli aracı da tazminat görüşmeleri olmuştur. Ancak durum beklenildiği kadar kolay olmamış, Güneydoğu Asya ülkeleri geçmişte yaşananlardan dolayı Japonya'ya korku ve şüpheyle yaklaşmışlardır. ${ }^{3}$

Diğer taraftan Güneydoğu Asya'daki ülkelerin çoğu Batı sömürge yönetiminden kurtulmuşlardır. Bağımsızlıklarını yeni kazanan Güneydoğu Asya ülkeleri, ortak çıkarları doğrultusunda karşılıklı ilişkilerini geliştirmek için 1955 yılında Bandung Konferansı'nı

\footnotetext{
${ }^{1}$ Hagiaki 2005, s. 188 .

${ }^{2}$ Tarling 2008, s. 363.

${ }^{3}$ Hagiaki 2005, s. 201.
} 
düzenlemeye karar vermişlerdir. Bu konferansa hâlâ sömürge altında bulunan Afrika'y1 da dâhil etmişlerdir. ${ }^{4}$ Bağımsızlıklarını kazanan bu yeni devletlerin bir araya gelmesi, II. Dünya Savaşı'ndan sonra dünya siyasetine yön veren Batı ve Doğu bloklarını, yani Amerika ve Sovyetler Birliği'ni etkilemiştir. Çünkü bu yeni devletler, Doğu ve Batı bloğunun dışında kalarak ekonomik kalkınma hedefinde Üçüncü Bloğu oluşturmaya çalışmışlardır. Ancak devletlerin iki bloğun dışında kalarak yardım almadan ekonomik kalkınma sağlamaları zordu. Dolayısıyla bunun anlamı da yardım alınacak bloğa bağlanmak demekti. Yardım almadan ekonomik anlamda bir şeyler başarabilmek kendi çıkarlarına olacaktı. Kaldı ki Batı'nın sömürgesinden yeni kurtuldukları için sömürgeciliğgin izlerini hâlâ taşıyorlardı. Bu durum da Batı'ya karşı temkinli yaklaşmalarına neden oluyordu. Aynı şekilde Doğu Bloğuna da katılmak istemiyorlardı. Üçüncü blok olarak birlikte bağımsızlıklarını daha iyi koruyacaklarına ve Doğu - Batı arasında dengeyi sağlayacaklarını inanıyorlardı. Bu amaçla büyük bir konferans düzenlemeye karar vermişlerdi. ${ }^{5}$

Bandung Konferansı Asya ve Afrika ulusları arasındaki iş birliğinin gelişmesi açısından önemli bir adımdı. Bu makalede, Asya'nın yeniden doğuşunu temsil eden ve uluslararası anlamda tarihi öneme sahip Bandung Konferans1 genel hatlariyla ele alınmıştır. Ayrıca Japon arşivlerinde yer alan Bandung Konferansı ile ilgili belgeler ışığında Japonya' nın bu konferanstaki rolünün ortaya konması hedeflenmiştir. Çünkü Japonya için Bandung Konferansı, Asya'ya geri dönmesi ve işgal döneminden sonraki yeni Japonya'yı Asya'ya göstermesi açısından bulunmaz bir şanstı. Aynı zamanda Japonya'nın yayılmacı siyasetinden vazgeçtiğini ve barışçıl bir dış siyaset benimsediğini kanttlayabileceği bir platformdu. Çalışmada ilk olarak 1945 yılından sonra düzenlenen ve Bandung Konferansı fikrinin filizlenmesini sağlayan bir dizi toplantılara kısaca değinilecek ve bu vesileyle Bandung Konferansı'nın alt yapısının nasıl oluştuğu anlaşılmaya çalışılacaktır. Ardından Japonya'nın konferansa davet edilme süreci ve konferanstaki varlığı ortaya konmaya çalışılacaktır.

\section{Bandung Konferansı'na Giden Süreç (1947-1954)}

1945 yılı sonrası Asya'nın siyasi durumu, Asya-Afrika Konferansı olarak da bilinen Bandung Konferansı'nın ortaya çıkmasına zemin hazırlamıştır. Asya ve Afrika ülkelerinden bağımsızlıklarını elde edenler bir araya gelip, iş birliği içerisinde olurlarsa sorunlarını çözebileceklerinin ve tek güç olabileceklerinin farkına varmışlardır. Bu düşünce Bandung Konferansı'nın kökenini oluşturmuştur diyebiliriz.

Bandung Konferansı'nın düzenlenmesi fikri 1947 yılına kadar uzanmaktadır. 1947 yılının Mart-Nisan aylarında Yeni Delhi'de Hindistan Dünya Meseleleri Konseyi liderliğinde Asya İliş̧kileri Konferansı (The Asian Relations Conference) düzenlenmiş̧tir. Konferansa Mısır, Çin, İran, Endonezya, Hindiçin, Türkiye, Kore, Moğolistan, Tayland, Malezya, Filipinler, Afganistan, Tibet, Nepal, Butan, Burma ve Sri Lanka'dan temsilciler, Avustralya ve Yeni Zelanda'dan gözlemciler katılmıştır. Bazı delegeler bu konferansta

\footnotetext{
${ }^{4}$ Purcell 1965, s. 203.

${ }^{5}$ Murat 2018, s. 367.
} 
Japonya'nın temsil edildiğini görmek istediklerini belirtmişlerdir. ${ }^{6}$ Ancak Japonya, hem o dönemde Amerika'nın işgali altında olduğundan hem de yayılmacı siyasetiyle Asya ülkelerine verdiği zarardan dolayı davet edilmemiştir. Hindistan Başbakanı Jawaharlal Nehru (1889-1964) konferansın açılış konuşmasında konferans fikrinin eskiye dayandığını, konferansta lider ve taraf olmadığını belirtmiştir. Dolayısıyla tüm Asya ülkelerinin ortak bir görev ve çabada eşit bir şekilde bir araya gelmek zorunda olduklarını, konferansın (aynı zamanda kökeninde yatan fikrin), başka bir ülkeye ya da kıtaya zarar vermek amacında olmadığını veya karşı olmadığını vurgulamıştır. Devamında da şu şekilde ifade etmiştir:

"Konferans ile ilgili haberler çıtı̆̆ğndan itibaren Avrupa ve Amerika'da bulunanların bazlları bu toplantının kendilerine yönelik bir tür Pan-Asya hareketi olduğundan şüphelendiler. Hiç kimseye karşı böyle bir düşüncemiz yoktur. Bizimki, tüm dünyada barışı ve ilerlemeyi teşvik eden harika bir tasarımdır. Bu hikâye artık geçmişe ait olmalıdır. Kendi ayaklarımızın üzerinde durmayı ve bizimle iş birliği yapmaya hazır olan diğer herkesle iş birliği yapmayı öneriyoruz. Ancak başkalarının da oyuncă̆ olma niyetinde değiliz. Dünya tarihindeki bu krizde Asya, mutlaka hayati bir rol oynayacaktır. Asya ülkeleri artık başkaları tarafindan piyon olarak kullanılamaz. Dünya meselelerinde kendi politikalarına sahip olmaları gereklidir."7

Jawaharlal Nehru, kendi ülkesi de dâhil konferansa katılan birçok ülkenin hâlâ sömürge altında olmasına rağmen, Asya'nın bağımsızlığının ilk kıvılcımlarını ve bölgenin dünya meselelerinde sessiz kalmayıp, ön planda olacağını ve Soğuk Savaş döneminde Asya'nın stratejik bir konuma sahip olacağını konuşmasında açıç̧a belirtmiştir. Konferansta her Asya ülkesinin karşılaştığı sorunlar olan bağımsızlık, 1rkçılık, kadınların statüsü, kültürel iş birliği gibi konular tartışılmıştır. ${ }^{8}$

1946-1949 yılları arasında Burma, Sri Lanka, Hindistan, Pakistan ve Filipinler gibi ülkelerin bağımsızlıklarını kazanmaları Asya'da duyarlılığın ve iş birliğin gelişmesine olanak tanımıştır. Hindistan Başbakanı Jawaharlal Nehru'nun çağrısı üzerine 1949 yılında Yeni Delhi'de Myanmar, Sri Lanka, Hindistan, Endonezya, Pakistan ve Filipinler gibi on beş Asya ulusu, yeniden bir araya gelerek başka bir konferans daha düzenlemişlerdir. Toplantının amacı Asya-Afrika dayanışması ve Endonezya'nın bağımsızlık sorunuydu. ${ }^{9}$ Toplantının yapıldığı dönemde Endonezya, Hollanda'ya karşı bağımsızlık mücadelesi vermekteydi. Dolayısıyla bu durum toplantının ana gündem maddesini oluşturmuş, Hollanda'nın Endonezya' ya yönelik askeri faaliyetleri kınanmıştır.

Yeni Delhi' deki toplantıdan bir yıl sonra 26-30 Mayıs 1950' de bu kez Filipinler' in Baguio şehrinde Güneydoğu Asya ülkelerinin katıldığı yeni bir konferans daha düzenlenmiştir. Baguio Konferansı'nın açılış konuşmasında Filipinler Devlet Başkanı Elpidio Quirino (1890-1956) şöyle ifade etmiştir:

"Yakın geçmişe kadar çoğumuz kendi rotamızı çizemedik ve yabancıların rehberliğine güvenmek zorunda kaldık. Bă̆lılıklarımız bölündü; kendi inisiyatifimizi

\footnotetext{
${ }^{6}$ Cairns Post, 29 Mart 1947, s. 1.

${ }^{7}$ The Tibet Sun, 24 Mart 1947.

${ }^{8}$ Apparodai 1955, s. 207; The Tibet Sun, 24 Mart 1947.

${ }^{9}$ Gotō 2003, s. 250.
} 
geliştiremedik; büyümemizi ayrı milletler olarak belirleyemedik. Artık kendi kaderimizin efendisi olduğumuza göre her birimiz, ulusal dehamızla tutarl, sistematik büyümemizi ve gelişmemizi sürdürmek için çabalamalıyı. Karşılıklı samimi istişarelerle ortak çıkarlarımızı daha iyi desteklemek için ortak tarihi kökenimize ve coğrafi yakınlı̆̆ımıza güvenerek birbirimizi tamamlayabileceğimize inanıyoruz. Bugün hepimiz için tarihi bir andır. Bu tarz konferansın düzenlenmesi için geç kalındı...Burada ortak çıkarlarımız için toplandı̆̆ımıza ve kimseye karşı olmadığımız konusunda hemfikir olduğumuza inanıyorum... Sembolümüz barış güvercinidir. Dünya düşmanlık ve güvensizlikle dolu, komplo ve gerilimle baştan sona vurulmuş haldedir. Bizim niyetimiz de uluslararası alanda hüküm süren kafa karışıklı̆̆ına ve korkuya ekleme yapmak değildir. Siyasi mücadelenin zorluklarını hafifletmeye ve tüm insanların dünyayı saran korkunç tehdit karşısında hissettiği kaygıyı hafifletmeye çalışmamız gerektiğine inanıyorum ... Dünyanın ilerlemesine, dünya barışına daha büyük bir birim olarak katkıda bulunma firsatına sahibiz. Şimdiye kadar, kendi seçimimiz olması gerekmeyen çatışmalara sürüklendik. Şimdi yıkım çağını geride bırakmak ve her zaman yeniden inşa etmek istiyoruz... "I0

Elpidio Quirino, tek bir konferansla ya da birçok konferansla her şeyin bir anda düzeleceğini düşünmediğini, ancak siyasi, ekonomik ve kültürel refahlarını ilerletmek için bölgesel iş birliği içinde olmaları gerektiği üzerinde durmuştur. Bölge halkını ilgilendiren bir konu olduğunda birbirlerine danışmalarını önermiştir. Tıpkı Jawaharlal Nehru'nun Asya İlişkileri Konferansı'ndaki konuşmasında olduğu gibi Quirino da bağımsızlığa, Asya'nın önemine vurgu yapmıştır. Her iki lider de Asya'nın ilerlemesi ve söz sahibi olabilmesi için iş birliğine dikkat çekmiştir.

Baguio'daki toplantıdan bir ay sonra Kore Savaşı başlamıştır. Asya'daki siyasi ve askeri gerilim iyice artmıştır. Bandung Konferansı'nın toplanması da o yıllardaki Asya'nın istikrarsız durumundan kaynaklanmıştır. Konferansın düzenlenmesine karar verildiği dönemde Kore Savaşı'nda sona gelinmiş, Çinhindi'deki Vietnam ve Fransa arasındaki savaşta da sona yaklaşılmıştı. Viet Minh kuvvetleri Dien Bien Phu'da Fransız kuvvetlerini kuşatmış, I. Çinhindi Savaşı'nı kazanmışlardı. Fransızların Çinhindi'ndeki varlığı neredeyse yok olmak üzereydi. Diğer taraftan Kore Savaşı'nda karşılıklı savaşan Amerika ile Çin, bu kez de Tayvan konusunda karşı karşıya gelmişti. Asya'da yaşanan bu gelişmeler Burma, Sri Lanka, Hindistan, Endonezya ve Pakistan başbakanlarını 28 Nisan - 2 Mayıs 1954 tarihleri arasında Seylan şehri Kolombo'da buluşmaya sevk etmiştir. Her ne kadar yukarıda belirttiğimiz konferanslar Bandung Konferansı'na giden yolda birer merdiven görevi görseler de konferansın kesin olarak düzenlenmesine 28 Nisan 1954 'teki Kolombo Konferansı'nda karar verilmiştir. Kolombo'da toplanan ülkeler; Hindiçin'de barışın sağlanması, Birleşmiş Milletlerde Çin Halk Cumhuriyeti'nin tanınması, Tunus ve Fas'ta sömürgeciliğin sona ermesi gibi ortak çıkarları ilgilendiren sorunlara karşı almaları gereken tutum üzerine tartışmışlardır. Kapanış bildirilerinde Kolombo katılımcıları, Güneydoğu Asya'da barış umutlarını, hidrojen bombasının geliştirilmesi konusundaki endişelerini ve sömürgeciliğe karşı olan genel tutumlarını dile getirmişlerdir. $^{11}$

\footnotetext{
${ }^{10}$ Official Gazette, 26 Mayıs 1950.

${ }^{11}$ Rakove 2018, s. 1.
} 
Kolombo'dan sonra 25 Eylül 1954'te Endonezya Başbakanı Dr. Ali Sastroamidjojo (1903-1976) ve Hindistan Başbakanı Jawaharlal Nehru ortak bir bildiri yayımlamışlardır. Buna göre; Asya ve Afrika ülkelerinin temsilcilerinin katıldığı bir konferans düzenleme konusunda görüştüklerini, bu tarz bir konferansın barışı destekleme ve sorunlara ortak yaklaşımda bulunma konusunda yardımcı olabileceğine dair fikir birliğine vardıklarını bildirmişlerdir. ${ }^{12} \mathrm{Bu}$ doğrultuda Kolombo'ya katılan ülkeler, 1954 yılının Aralık ayında Cakarta'nın güneyinde yer alan Bogor'da yeniden bir araya gelerek Bandung Konferansı'nın son hazırlıklarını tamamlamışlardır. Toplantının sonucunda; konferansın nerede yapılacağına, konferansa katılacak ülkelere, konferansın içeriğine ve amacına, aynı zamanda konferansin temsilinin bakanlık düzeyinde olmasına, buna göre davet edilen her bir ülkenin başbakan ya da Dışş̧̧leri Bakanı tarafından temsil edilmesine karar verilmiştir. ${ }^{13}$

\section{Bandung Konferansi (1955)}

Tarihin ilk Asya-Afrika konferansı olan Bandung Konferans1, 18-24 Nisan $1955^{\prime}$ te Asya ve Afrika'dan yirmi dokuz ulusun katılımıla Batı Cava'da bulunan Bandung'ta düzenlenmiştir. Konferansın ev sahipliğini Burma, Endonezya, Hindistan, Pakistan ve Sri Lanka başbakanları yapmıştır. Konferansın tarihi dinî unsurlar göz önüne alınarak belirlenmiştir. Şöyle ki toplantının düzenlendiği yıl Nisan ayının yirmi dördü ve yirmi beşi, Ramazan ayının başlangıcı olduğu için birçok Müslüman Arap ülkeleri toplantıya katılamayacaktı. Bunun yanı sıra aynı dönemde Burma Başbakanı, Budizm'in kutsal günü olduğu için 16 Nisan'a kadar ülkesinden ayrılamamaktaydı. Bundan dolayı konferansın 18 Nisan'da başlayıp, 23 Nisan'da bitmesi en uygun tarih olarak görülmüş ve bu tarih aralığında düzenlenmesine karar verilmiştir. ${ }^{14}$ Peki, mekân olarak niçin Endonezya'nın başkenti ve en büyük şehri olan Cakarta değil de Bandung seçilmişti? Öncelikle Bandung, uluslararası konferansı kaldıracak temel kriterlere sahipti. Ayrıca sadece bir Endonezya şehri değil, aynı zamanda sömürge sonrası Endonezya seçkinleri için bile özel bir yerdi. Çünkü Sukarno gibi birçok seçkinin, öğrencilik ve özgürlükleri için savaşıtıları yıllarda ev sahipliği yapmış sembolik bir yerdi. Unutulmaması gereken bir diğer özelliği de Bandung'un Endonezya Cumhuriyeti’nin meşruiyetine karşı çıkan Darul İslam Hareketi'nin kalesi olmasiydı. Bu sebeplerden dolayı konferans Bandung'ta düzenlenmiştir. Konferansın gerçekleştiği şehir kadar toplantının yapıldığı binanın adı da ilginçtir. Toplantı binası, 1895 yılında Bandung ve çevresinde yaşayan Avrupalılar için bir buluşma yeri olarak inşa edilmiş ve Concordia Society ${ }^{15}$ olarak adlandırılmışıtır. ${ }^{16}$

\footnotetext{
12 Apparodai 1955, s. 208-209.

${ }^{13}$ Sano 1999 , s. 128.

${ }^{14}$ Shimazu 2014, s. 235.

${ }^{15}$ Concordia Derneği.

${ }^{16} \mathrm{Bu}$ yeri kullananların çoğunluğu çay tarlası sahipleri ya da Hollandalı subaylardı. Bina 1921 yılında tasarımcı C. P Wolff Schoemaker tarafından modern mimaride yeniden inşa edilmiştir. Japon işgali sırasında (1942 - 1945) binanın adı Dai Toa Kaikan olarak değiştirilmiş ve kültür merkezi olarak kullanılmıştır. Endonezya'nın bağımsızlık ilanından sonra bina, teslim olmak istemeyen Japon birliklerine karşı savaşan Endonezyalı gençlerin karargâhı olmuştur. 1949 yılına
} 


\section{Özgürlük Yolu: Bandung Konferansl ve Japonya}

Sukarno, 7 Nisan 1955 'te konferans hazırlıklarını incelemek için Bandung'u ziyaret ettiğinde, konferansın ve ev sahibi ülke olarak bağımsızlı̆̆ını yeni kazanmış Endonezya'nın ruhunu daha iyi yansıtacak şekilde binanın adını değiştirmeye karar vermiş̦tir. Ardından binanın adı Freedom Building ${ }^{17}$ (Gedung Merdeka) olarak yeniden düzenlenmiş ve toplantı bu binada yapılmıştır. ${ }^{18}$

Bandung Konferansı'na Asya ve Afrika'dan olmak üzere yirmi dokuz ülke katılmıştır. Konferansa iştirak eden ülkeler; Afganistan, Kamboçya, Çin Halk Cumhuriyeti, Misır, Etiyopya, Gana, İran, Irak, Japonya, Laos, Libya, Ürdün, Lübnan, Liberya, Nepal, Filipinler, Suudi Arabistan, Sudan, Suriye, Tayland, Türkiye, Kuzey Vietnam, Güney Vietnam ve Yemendi. ${ }^{19}$ Toplantıya katılan ülkelerden de anlaşılacağ 1 üzere Batılı ülkelerin katılmadığı ilk uluslararası toplantıydı. Asya ve Afrika'nın bağımsız devletleri, sömürge güçlerinden, Amerika ve Sovyetler Birliği gibi nükleer süper güçlerden bağımsız olarak kendi kaderlerini belirlemek için toplanmışlardır. Farklı kültürlerden ve irklardan olan bu ülkeleri bir araya getiren sebep, sömürgeciliğe ve emperyalizme karşı benimsedikleri ortak siyasi tutumlarıydı.

Bandung Konferansı'nın amacı, Asya ve Afrika ulusları arasındaki iş birliğini desteklemek; karşılıklı olarak ortak çıkarları geliştirmek; dostluk ilişkileri kurmak; katılımcı ülkelerin sosyal, ekonomik ve kültürel problemleri ile ilişkileri üzerine tartışmak; Asya ve Afrika halklarını özel olarak ilgilendiren sorunları ele almak (örneğin; ulusal egemenlik, ırkçılık ve sömürgecilik gibi.); Asya ve Afrika'nın günümüzdeki konumunu değerlendirmek; Asya ve Afrika'nın dünya barışı ve iş birliğini destekleme konusunda yapabilecekleri katkıyı görmekti. ${ }^{20}$ Siyasi sistemleri farklılık gösterse dahi katılımcı ülkeler arasında karşılıklı anlayışı derinleştirmek, iş birliğini geliştirmek ve sömürgecilik hakkında tartışmak toplantının öncelikleriydi denilebilir. Nitekim konferansta sömürgeleştirmeye karşı çıkılarak, karşılıklı dayanışma dile getirilmiştir.

Bandung Konferansı 18 Nisan 1955'te Sukarno'nun açılış konuşmasındaki “Yeni Asya ve Afrika doğuyor" sözleriyle başlamıştır. Sukarno konuşmasında ırklara ve dinlere

gelindiğinde ise bina yeniden dinlenme yeri olarak kullanılmaya başlanmıştır. Bkz: http://asianafricanmuseum.org/ Erişim Tarihi: 22.11.2021, 16:25.

17 Özgürlük Binası.

${ }^{18}$ Shimazu 2014, s. 235-249.

${ }^{19}$ Konferansa coğrafik olarak Asya'nın bir parçası olmasına rağmen Avustralya davet edilmemiştir. Oysa Avustralya'nın bölgede çıkarı da bulunuyordu. Ancak Avustralya komşusu olan Asyalılara karşı o kadar sempati beslememiş ve onları anlamaya da çalışmamıştır. Uygulamış olduğu göç politikasından anlaşıldığı kadarıyla konumuna rağmen kendini Asya'dan ziyade Avrupa'ya ait hissetmiştir. O dönemlerde Asya ve Arap blokları tarafından Birleşmiş Milletler'de ırk ve sömürge sorunları gündeme geldiğinde, Avustralya sürekli olarak Avrupalı sömürgeci güçleri desteklemiştir. Elbette Avustralya ve Yeni Zelanda'nın Bandung'dan hariç tutulmasının resmi açıklaması, konferans alanının sınırlandırılmış olmasıydı. Bkz: Rao 1955, s. 312-313. Ancak Avustralya'nın katılmamasına rağmen Nehru konferansta, Avustralya ve Yeni Zelanda'nın Asya'ya yaklaşmasını istediğini belirtmiştir. Bkz: The Northam Advertiser, 6 Mayıs 1955, s. 7.

${ }^{20}$ Apparodai 1955, s. 209; Redding 1956, s. 413; Wright 1956, s. 11. 
hitap ederek, "bu, insanlık tarihinde renkli halklartn ilk uluslararası konferansıldr." 21 şeklindeki sözleriyle toplantının özelliğine dikkat çekmiştir. Yoğun duygular içerisinde olduğunu belirten Sukarno, insanlık tarihinde siyahi insanların da katıldığı ilk uluslararası konferansı düzenleme şerefine eriştiklerini dile getirmiştir. Konferansa katılan herkesin bir bütün olduğunu, sömürgecilik ya da rrkçılık nefreti paydasında bütünleştirildiklerini ifade etmiştir. ${ }^{22}$ Zaten benzer sömürge geçmişleri ve sömürgeciliğe karșı verdikleri mücadele dışında, bu ulusların ortak bir noktası bulunmuyordu. Sukarno Bandung Konferansı'nın özünü de şu şekilde açıklamıştır:

"Bu Müslümanlık, Hristiyanlık ya da Budizm konferansı değil, bu kardeşlik konferansıdır. Malayalıların, Arapların ya da Hintlilerin toplantısı değildir. Özel bir kulüp ya da başka bir blok önermeyi amaçlayan blok da değildir. Aksine, tüm erkeklerin ve tüm ülkelerin güneş altında yerlerini aldıklarl; birlikte yaşamanin, bir araya gelmenin, bireysel kimliğini kaybetmeden, karşıllklı konuşmanın mümkün olduğu; kaygı verici ortak konuların genel olarak anlaşılmasına katkıda bulunmak, insanların karşılıklı bağımlılığı konusunda gerçek bir bilinç geliştirmek, ulusların yeryüzündeki refahları ve hayatta

${ }^{21}$ Devamında da şöyle demiştir: "Kardeşlerim, zaman ne kadar da hızlı. Birkaç yıl önce sömürgeciliğin kamuya açık bir analizini yapma firsatımın olduğunu ve "emperyalizmin yaşam hattı" dediğim şeye dikkat çektiğimi hatırlıyorum. Bu hat, Cebelitarık Boğazı'ndan Akdeniz, Süveyş Kanalı, Kızıldeniz, Hint Okyanusu, Güney Çin Denizi ve Japon Denizi boyunca uzanır. $\mathrm{Bu}$ yaşam çizgisinin her iki tarafındaki bölgeler koloniydiler. İnsanlar özgür değildi, gelecekleri yabancı bir sisteme ipotek edilmişti. Emperyalizmin ana damarı olan bu yaşam çizgisi boyunca sömürgeciliğin can damarı pompalanırdı. Bugün burada fedakârlıklar sonucunda toplandığımızı kabul ediyorum. Atalarımız, bizimler ve genç kuşaklar tarafından yapılan fedakârlıklar... Onların bu mücadeleleri ve fedakârlıkları, dünyanın en büyük iki kıtasından bağımsız ve egemen ulusların en yüksek temsilcilerinin buluşmasının önünü açtı. Bu bağlamda, yaklaşık otuz yıl önce Brüksel'de düzenlenen "Emperyalizm ve Sömürgeciliğe Karşı Birlik Konferansı'nı" hatırlıyorum. O konferansta bugün burada bulunan birçok seçkin delege birbirleriyle tanıştı ve bağımsızlık mücadelelerinde yeni bir güç buldular. Bir korku dünyasında yaşıyoruz. Bugün insanın yaşamı korkuyla aşınmış ve acı bir hale getirilmiştir. Gelecek korkusu, hidrojen bombası korkusu, ideolojilerden korkma. Belki de bu korku, tehlikenin kendisinden daha büyük bir tehlikedir. Çünkü insanları aptalca davranmaya, düşüncesizce davranmaya, tehlikeli davranmaya iten korkudur... Okyanusların ve denizlerin bizi koruyacağını düşünmeyin. Yediğimiz yiyecekler, içtiğimiz su, evet soluduğumuz hava bile binlerce mil öteden kaynaklanan zehirlerle kirlenebilir. Ve biz kendimiz kaçsak bile çocuklarımızın doğmamış nesilleri, dünyada serbest bırakılan güçleri kontrol edemememizin izlerini bozuk bedenlerinde taşıyabilirler. İnsanlarımız nesiller boyunca dünyadaki sessiz insanlar oldular. Bizler, çıkarları başkaları tarafından karar verilen halklar, yoksulluk içinde yaşayan ve aşağılanan halklar olduk... Ne yapabiliriz? Asya ve Afrika halkları fiziksel olarak güçsüzler. Ekonomik gücümüz bile dağınık ve az. Güç siyasetine düşkün değiliz... Devlet adamlarımız sıralı jet bombardıman uçaklarıyla desteklenmiyor. Asya ve Afrika'nın nüfusu, dünya nüfusunun yarısından fazladır. Barış lehine "Milletlerin Ahlaki Şiddeti”" dediğim şeyi seferber edebiliriz. Din, özellikle dünyanın bu bölgesinde baskındır. Belki de burada dünyanın diğer bölgelerine göre daha fazla din var... Ülkelerimiz dinlerin doğum yeridir. Hemen hemen hepimizin ortak sömürgecilik deneyimiyle bağları var.” Bkz: Wright 1956, s.118120.

${ }^{22}$ Redding 1956, s. 415. 


\section{Özgürlük Yolu: Bandung Konferansl ve Japonya}

kalmaları için dünyayı etkilemek isteyen aydın ve hoşgörülü bir düşüncenin vücut bulmuş halidir. "23

Bandung ile ilgili olarak Jawaharlal Nehru ise konferansın saldırgan milliyetçiliğin ifadesi değil, kişinin kendi ruhunu geri kazanması, diş güçlerin müdahalesinden kurtulma dürtüsü olduğunu belirtmiştir. Konferansın yeni, tarafsız bir güçler bloğu yaratmak için değil, Afrika ve Asya uluslarının hemfikir olabileceği ve onları doğrudan ilgilendiren konuları keşfetmek için düzenlendiğini savunmuştur. ${ }^{24}$ Ancak buna rağmen Batılılar, üçüncü bir bloğun kurulmasından ve endüstrileri için bu ülkelerin hammaddelerinden yoksun kalacakları düşüncesiyle endişe etmişlerdir. Bu noktada haksız da sayılmazlardı. Bandung Konferansı'nın Batı karşıtı duyguları harekete geçirme, komünist bir ülke olsun ya da olmasın Asya ülkesi olarak dayanışma duygusunu güçlendirme riski olduğu için doğrudan olmasa da Batı'y1 etkiliyordu. Konferans Asya ülkeleri ile Batı arasındaki uçurumun derinleşmesine neden olabilirdi. Bu durumun da Çin ve Sovyet tarafına fayda sağlayacağı kaygısı vardı. ${ }^{25}$ Dolayısıyla Batılı müttefikler Bandung görüşmesiyle ilgili endişelenmişlerdir. Amerikan hükümeti, Çin'in etkisini genişletmeye yönelik böyle bir toplantıya ihtiyatla yaklaşmıştır. Ancak Amerika, konferansın yapılmasına engel olmaya çalışmanın ya da Kolombo Grubu ile olan ilişkisi de göz önüne alındığında, Amerika yanlısı Asya ülkelerinden konferansa katılmamalarını isteyerek toplantıyı değersizleştirmenin akıllıca bir strateji olmadığının da farkındaydı. Dışişleri Bakanı John F. Dulles (1888-1959), Bandung'u eleştirerek "Böyle bir konferans keşke yapılmasaydı." şeklinde söyleyip eklemiştir: "Ama ĕger yapılacaksa, dost ülkelerin en iyi temsilcilerinin Bandung'a katılımlarını sağlamalıyız ve onları bilgi anlamında en iyi şekilde donatmalıyız." ${ }^{26}$ Sonuç olarak konferansa doğrudan etki edemeyen Eisenhower yönetimi, Dulles'ın da belirttiği gibi konferansta Batılı görüşü ilerletmek için dostane katılımcılar toplamaya çalışmıştır. Amerika'nın uygulamaya çalıştığ 1 taktik, kendi tarafında olan Asya ülkelerinin Çin'e karşı yetkin bir heyet göndermesini sağlayarak konferansın tarafsızlar ya da komünistlerin tarafından ziyade sağlıklı bir yöne yönlendirmekti. ${ }^{27}$

Batılı güçlerin endişelerinin farkında olan Jawaharlal Nehru Bandung Konferansı'ndaki “Bizler, Avrupa ve Amerika ile dost olmak, iş birliği yapmak istiyoruz. Oysa onlar, kendi kavgalarının dünyanın kavgası olduğunu ve dünyanın onlara şu ya da bu şekilde boyun ĕgmesi gerektiğini düşünme alışkanlı̆̆ içindedirler. Neden bizler onların kavgalarının ya da savaşlarının içine sürüklenelim? Umarım uzak dururuz." 28 şeklindeki yapıcı ifadeleriyle konferansa yönelik önyargıları biraz olsun azaltmak istemiştir. Diğer taraftan Filipinli diplomat Carlos Romulo (1899-1985) anılarında bu konferans ile ilgili olarak "yeni Asya ve Afrika ruhunun ilk çiçek açması" ${ }^{29}$ şeklinde ifade

\footnotetext{
${ }^{23}$ Dennehy 2011.

${ }^{24}$ Fitzgerald 1955, s. 9.

25 Taizō 2017, s. 43-44.

${ }^{26}$ Rakove 2018, s. 2.

${ }^{27}$ Rakove 2018, s. 2.

28 The Northam Advertiser, 6 May1s 1955.

${ }^{29}$ Shimazu 2014, s. 227.
} 
ederek, aslında Batılıların korkusunun yersiz olmadığını, Asya ve Afrika halklarında Batılılara karşı bir uyanışın olduğunu göstermiştir. McTurnan Kahin ve Richard Wright'ın sözleri de bu durumu destekler niteliktedir. Bandung Konferansı'nı yakından takip eden ve konferansa katılan birçok kişi ile birebir konuşma şansı yakalayan McTurnan Kahin "The Asian-African Conference" adlı eserinde, bu konferansın bir çok delegeye özgüven aşıladığını ifade etmiştir. ${ }^{30}$ Aynı şekilde gözlem yapmak üzere konferansa katılan ve anılarını "The Colour Curtain" adlı eserinde kaleme döken Richard Wright'e göre; Bandung, geleneklerinden ve göreneklerinden olumsuz bir şekilde kurtulmuş insanlığı temsil ediyordu. Bandung'taki konferans, insan olarak insanın kendini organize etmesi için tarihteki ilk girişimdi. Irkçılık, Batı'nın Asya ve Afrika'yı kontrol altında tutmak için kullandığı bir araçtı. Ancak Bandung Konferansı ile durum değiş̧mişti. Artık lider Batı değil, Asya ve Afrika uluslarıydı. Bu uluslar nesne değil, özne konumundaydilar. ${ }^{31}$

Batı medyası Bandung Konferansı'nı eleştirmiştir. Örneğin; New York Times gazetesi Bandung'un gerçek anlamda bölgesel bir toplantı olmadığını belirtmiş̧tir. Haberin içeriğinde toplantıda üzerinde durulan sorunların Gana'dan ziyade Avustralya ve Yeni Zelanda'yı daha çok ilgilendirdiği, ancak bu ülkelerin davet edilmediği vurgulanmıştır. İki ülkenin yanı sıra, Güney ve Kuzey Kore, aynı zamanda İsrail ve Güney Afrika da konferansa davet edilmemiştir. Dolayısıyla bu ülkelerin çağrılmaması toplantının bölgesel olmadığının göstergesiydi. ${ }^{32}$ Boston'daki Christian Science Monitor gazetesi ise 23 Ocak 1955 tarihinde konferansın anlamını şu şekilde okuyucularına aktarmıştır: "Batı hariç tutulmuştur. Vurgu, dünyanın renkli ulusları üzerinedir. Ve Asya için bunun anlamı, en sonunda Asya'nin kaderinin Cenevre, Paris, Londra ya da Washington'da değil, Asya'da belirlenmesidir. Sömürgecilik söz konusu değildir. Çek elini denmektedir. Asya özgürdür. Bu belki de yüzyllımızın büyük bir tarihi olayıdır. "’33

Konferansın düzenlendiği yıl görüşlerini dile getiren araştırmacılar da olmuştur. $\mathrm{Bu}$ araştırmacılardan biri ve Ivy League'in ilk Siyahi öğretim üyesi olan Saunders Redding şöyle ifade etmiştir:

"Bandung Konferansı, Batı'yı 25 ylllı en önemli gerçekle ve bir soruyla yüzleştirmiştir. Afrika ve Asya halkı ne yapmak istiyor, yani bu insanlar ne istiyor? Cevap aynı zamanda konferansin içeriğinde verilmiştir. Onlar iş birliği istiyorlar, ekonomik yardım istiyorlar, dünyanın kaynaklarını paylaşmak istiyorlar. Ancak en önemlisi insan olarak eşitliklerinin kabul edilmesini istiyorlar. Yani insan olarak eşit sayılmak istiyorlar." 34

Yukarıdaki alıntıdan da anlaşılacağı üzere Saunders Redding, Batı'nın artık Asya ve Afrika halklarına saygı duyması gerektiğini, bu ulusların kendilerinin eşiti oldukları gerçeğini kabul etmelerinin zamanının geldiğini vurgulamıştır. Redding kendisi de siyahi olduğu için sözleriyle Batı ile ilgili kişisel düşüncelerini de dile getirmiştir diyebiliriz.

\footnotetext{
${ }^{30}$ Shimazu 2014, s. 228.

${ }^{31}$ Wright 1956, s. 57, 174-175.

${ }^{32}$ Prashad 2007, s. 40.

${ }^{33}$ Wright 1956, s. 74.

${ }^{34}$ Redding 1956, s. 420.
} 


\section{Özgürlük Yolu: Bandung Konferanst ve Japonya}

Musthtaq Ahmed ise "Bandung Konferansı, bazı iyi tanımlanmış hedeflerin takibi ve ilerlemesi için Asya ve Afrika kamuoyunu harekete geçirmeye yönelik ilk ve büyük bir sistematik girişimdi." şeklinde ifade eder. ${ }^{35}$ Bir diğer araştırmacı Venakata Rao, Bandung Konferansı'nı dünyanın en önemli olayı ve bir arada yaşamanın güzel bir örneği olarak nitelendirir. Çünkü farklı ideolojiden birçok ulus konferans sayesinde bir araya gelmiştir. Ona göre konferans; Avrupa diplomasisinin egemenliği veya etkisi olmaksızın, Asya ve Afrika uluslarının çoğunluğunun ortak sorunlarını tartışmak için ilk kez bir araya gelmesi açısından tarihseldir. Yani bu uluslar, karşılıklı ilişkilerinin nasıl olacağına dışarıdan bir müdahale olmaksızın kendi içlerinde belirlemeleri gerektiğine karar vermişlerdir. Çünkü Asya, yaklaşık elli yıl Avrupalı güçlerin sömürgesinde kalmıştır. Ancak bugün pozisyonları farklıdır. Asya büyük anlamda özerkliğini kazanmıştır. Ekonomik anlamda sıkıntı yaşadıkları ve bazı problemleri olduğu gerçektir. Ancak Asya artık özgürdür. ${ }^{36}$

Bandung Konferansı'nda ekonomik ve kültürel iş birlik, insan hakları ve özerklik, bağımsızlığını henüz kazanamamışların sorunları ve dünya barışı olmak üzere beş noktaya odaklanılmıştır. Her ne kadar konferansta Asya ve Afrika'nın kültürel ve ekonomik birliği hakkında konuşulsa da yukarıda da değindiğimiz gibi dünyanın, özellikle Batı'nın gözü bu konferansın üzerinde olmuştur. Bundan dolayı konferansta, Birleşmiş Milletler Şartı'nda belirtilen İnsan Hakları Temel İlkelerine tam destek verildiği beyan edilmiştir. Katılımcılar, ulusların özerklikleri için gerekli olan tüm yardımları yapacaklarını dile getirmişlerdir. ${ }^{37}$ Ayrıca Bandung'da silahsızlanma sorunu ele alınmış, kitle imha silahlarının üretimi ve kullanımı oybirliğiyle kınanmıştır. Evrensel silahsızlanmanın barışın korunması için mutlak bir zorunluluk olduğuna karar verilmiş ve Birleşmiş Milletlerden barışın korunması için çabalarını sürdürmeleri talep edilmiştir. Tüm silahlı kuvvetlerin ve silahlanmanın düzenlenmesi, sınırlandırılması, kontrol altına alınması ve azaltılması için ilgililere çağrıda bulunulmuştur. ${ }^{38}$ Çünkü toplantıya katılan devletler, gelecekte bir çatışma çıkması halinde silah bakımından yetersiz kalacaklarının farkındaydılar. Bundan dolayı silahsızlanma konusuna önem vermişler, kendileri gibi herkesin de bu konuda sağduyulu davranmalarını istemişlerdir.

Bandung'ta hâlâ bağımsızlıklarını kazanamamış olan ulusların problemleri de gündeme getirilmiştir. Katılımcılar, sömürgeciliğin tüm tezahürleriyle kötü olduğuna ve bağımsızlığın tüm insanlığa verilmesi konusunda hemfikir olmuşlardır. Özellikle Tunus, Fas ve Cezayir halklarının kendi kaderlerini tayin etme hakkı desteklenmiştir. Ayrıca Hollanda hükümetine, Endonezya ile arasındaki ilgili anlaşmalara dayanarak müzakereleri yeniden başlatması çağrısında bulunulmuştur. ${ }^{39}$

Diğer taraftan Bandung'da üzerinde durulan asıl mesele silahsızlanma ya da sömürgecilik değil, ekonomik iş birliği olmuştur. Konferansın sonunda Asya-Afrika ülkelerinin temel problemlerinin milli geliri yükseltmek olduğunun farkına varılmış ve bu bölgelerdeki halkların yaşam standartlarını iyileştirmek amacıyla ekonomik

\footnotetext{
${ }^{35}$ Mushtaq 1955, s. 362.

${ }^{36}$ Rao 1955, s. 312-313, 324.

${ }^{37}$ Apparodai 1955, s. 213.

${ }^{38}$ Sano 1999, s. 138.

${ }^{39}$ Apparodai 1955, s. 214.
} 


\section{Emine SICIM KAPLAN}

kalkınmanın teşvik edilmesinin gerekli olduğu üzerinde durulmuştur. Bu amaçla, katılımcı ülkeler arasında ekonomik iş birliği olması, her birinin genel isteği olmuştur. Bandung katılımcıları bölge içi birlikteliğin yanı sıra, dış yardımlara da ihtiyaçları olduklarının farkına varmışlardır. Bununla ilgili olarak ekonomik kalkınmaları için özel bir Birleşmiş Milletler Ekonomik Kalkınma Fonu ve Uluslararası Finans Kurumu kurulması gibi talepte bulunmuşlardır. ${ }^{40}$

Toparlamak gerekirse Bandung Konferansı'nda; Asya-Afrika güçleri arasındaki ekonomik iş birliği vurgulanmış; yabancı sermayeye sıcak bakılmış; ortak finansal girişimler teşvik edilmiş; katılımcı ülkelerin mümkün olan her yerde kendi hammaddelerini işlemeleri tavsiye edilmiş; kendi aralarında banka kurmanın gerekliliği üzerinde anlaşılmış; nükleer enerjinin barışçıl amaçlar için kullanılması gerektiği vurgulanmış; silahlanmanın düzenlenmesi konusuna dikkat çekilmiş; aralarındaki bilgi alışverişini kolaylaştırmak için katılımcı ülkelerin her birine irtibat görevlileri atama kararında hemfikir olunmuştur.

\section{4)}

\section{Bandung Konferansı'na Giden Süreçte Japonya'nın Siyasi Durumu (1945-}

II. Dünya Savaşı'nda yayılmacı bir politika izleyen Japonya, savaştan yenik olarak çıkmış ve yaklaşı yedi yıl Amerika'nın öncülügünde müttefik güçlerin işgalinde kalmıştır. İmparator Shōwa resmi olarak teslimiyetlerini 15 Ağustos 1945 'te radyodan ilan etmiştir. Teslim belgeleri ise 2 Eylül 1945'te Tokyo körfezinde demirli Missouri savaş gemisinde imzalanmış ve aynı gün Müttefik Kuvvetler Yüksek Komutanlığı (SCAP) kurulmuştur. Komutan olarak Japonya'yı yönetmesi için Amerikan Generali Douglas MacArthur (1880-1964) atanmıştır. ${ }^{41}$ İşgal 1945 yılıın Eylül ayında başlamış ve 28 Nisan 1952 tarihine kadar sürmüştür. Bu dönemde Japonya'da sosyal, askeri, ekonomik ve siyasi alanlarda reformlar uygulanmıştır. Reformlar şekillendirilirken Japonya'nın yeniden militarist politikalar takip etmesini engelleyecek şekilde olmasına dikkat edilmiştir. Dolayısıyla işgal reformlarının gerçekleştirilebilmesi için öncelikle Japon devlet yapısındaki militarist ve milliyetçi yapıyı yok etmek, ülkedeki demokratik eğilimleri güçlendirmek, ülkenin silahsızlanmasını sağlamak gibi konularda adımlar atılması gerekmiştir. Bu doğrultuda yeni bir anayasaya gerek duyulmuş ve 3 Mayıs 1947'de dünyanın en liberal anayasalarından biri olan Japonya'nın yeni anayasası yürürlüğe girmiş̧tir. ${ }^{42} \mathrm{Bu}$ anayasada özellikle dokuzuncu madde dikkat çekmiştir. Dokuzuncu madde şu şekildedir: "Adalet ve düzene dayalı uluslararası barışı içtenlikle arzulayan Japon halkl, kara, deniz ve hava kuvvetleri ile diğer savaş potansiyelini muhafaza etmeyeceğini ve devletin savaşma hakkını tanımayacağını beyan eder." "Bir önceki paragrafin amacın gerçekleştirmek için Japon halkı, ulusun egemen bir hakkı olarak savaşmaktan ve uluslararası anlaşmazlıkları çözmede tehdit veya güç kullanımından sonsuza dek vazgeçer. " 43 Bu maddeye göre Japon halkı sonsuza dek savaş

\footnotetext{
${ }^{40}$ Prashad 2007, s. 44.

${ }^{41}$ Holcombe 2017, s. 314.

${ }^{42}$ Çakmak 2013, s. 194.

${ }^{43}$ Lu 1996, s. 484.
} 


\section{Özgürlük Yolu: Bandung Konferansl ve Japonya}

hakkından vazgeçerken, Japonya kara, hava ve deniz kuvvetlerine sahip olamayacaktır. İşgalin amacı da Japonya'yı askersizleştirmek ve demokratikleştirmektir. Bu doğrultuda anayasayla birlikte savaştan önceki Japonya'nın yayılmacı politikası ortadan kaldırılmış, ülke askersizleştirilmiş ve silahsızlandırılmıştır. Nitekim anayasanın ilan edilmesinin ardından Japon ordusu da terhis edilmiştir.

II. Dünya Savaşı sona erdikten sonra Asya'nın tarihinde de büyük bir hareketlenme olmuştur. Kore Yarımadası 38. Enlem sınır kabul edilerek güneyden Amerika, kuzeyden de Sovyetler Birliği olmak üzere işgal edilmiştir. Çin anakarasında da durum pek iç açıcı değildir. Komünistler ve milliyetçiler arasında yaşanan gerilim ülkede iç savaşın patlak vermesine neden olmuştur. Doğu Asya'da yaşanan bu gelişmeler Amerika'nın Japonya'ya yönelik bakış açısını değiştirmesini sağlamış, ülkenin bağımsız olmasını gerekli kılmıştır. Çünkü Amerika için artık sorun Japonya'nın dünya barışına tekrardan tehdit olmasından ziyade komünizmin dünyaya yayılmasıdır. Bu doğrultuda Amerikan Başkanı Harry S. Truman (1884-1972), John F. Dulles'ı barış görüşmeleri için görevlendirmiştir. Dulles 1950 yılında görüşmeler için Japonya'ya gittiğinde Kore Savaşı patlak vermiştir. ${ }^{44} \mathrm{Bu}$ savaş Asya'daki siyasi ve askeri anlamda gerilimin zirveye ulaştığının göstergesi olmuş, iki ülke arasındaki barış antlaşması sürecini daha da hızlandırmıştır. Amerika, Japonya'da bulunan askerlerinin bir kısmını Kore'ye göndermiş, Japonya'yı da ordusu için üs olarak kullanmıştır. Ülkedeki iç güvenliğin sağlanması için de General MacArthur'un talimatı doğrultusunda, Japonya'nın yetmiş beş bin kişilik Ulusal Polis Teşkilatı ve on sekiz bin kişilik de Deniz Güvenlik İdaresi kurmasına izin verilmiştir. Bu sayede ordusundaki askerlerinin tamamına yakınının ya terhis edilmiş ya da sivil işlere yönlendirilmiş durumda bulunan Japonya, sınırlı sayıda da olsa askeri kapasite oluşturma şansına sahip olmuştur. Kore Savaşı aynı zamanda Japonya'nın Amerika'nın yeni müttefiki olmasını da sağlamıştır. ${ }^{45}$

Uzakdoğu'da yaşanan bu gelişmeler Amerika için Japonya'nın stratejik anlamda önemini artırmış, Japonya'nın bağımsız olması artık kaçınılmaz hale gelmiştir. Bu doğrultuda John F. Dulles, 1951 yllında tekrardan Japonya' ya giderek dönemin başbakanı Yoshida Shigeru $^{46}(1878-1967)$ ile bir araya gelmiş ve yapılacak olan barış antlaşmasının detaylarını görüşmüş̧ür. Yohsida antlaşmadan ziyade Amerika ile ilişkileri ilerletmeye önem vermiştir. Ona göre ülkesinin güvenliği ve kalkınması için Amerika ile iş birliği elzemdir. Çünkü Japonya'nın yapabileceği çok fazla bir şey yoktur. Ülke tamamen silahsızlandırılmıştır. Dolayısıyla silahlanmanın getireceği mali yükten kurtulma ve yeniden kalkınma doğrultusunda Amerika ile iş birliği kurmak, işleri oldukça kolaylaştıracaktır. Yoshida bununla ilgili olarak Japon halkına refaha eriştirecek olan en etkili ve yegâne yolun Amerika ile ittifak kurmaktan geçtiğini dile getirmiş̧tir. ${ }^{47}$ Japon ulusal politikasının silahsızlanma, ticaret ve Amerika ile iş birliğinden oluşan üç temel etmen literatürde Yoshida Doktrini olarak adlandırılmıştır. 8 Eylül 1951 tarihinde de kırk

\footnotetext{
${ }^{44}$ Gönen 2007, s. 80-81.

${ }^{45}$ Gönen 2007, s. 82.

46 吉田茂。

${ }^{47}$ Huffman 2015, s. 129.
} 
sekiz ülke ile San Fransisko Barış Antlaşması imzalanmıştır. ${ }^{48}$ Barış Antlaşması 1952 yılının Nisan ayında yürürlüğe girmiştir. San Fransisko Barış Antlaşması ile eş zamanlı olarak Amerika ve Japonya kendi aralarında Güvenlik Antlaşması imzalamışlardır. Bu antlaşmalarla Japonya'nın yedi yıllık işgal süreci sona ermiş ve Japonya bağımsız ülke olarak uluslararası sisteme yeniden katılmıştır. Elbette işgalin resmi anlamda sona ermesi Amerika'nın Japonya'dan tam anlamıyla geri çekildiği anlamını taşımıyordu. Amerika Japon adalarında üs kurma ve Okinawa Adası'nı kontrol etme haklarına sahip olmuştur. Günümüzde de Amerikan ordusu Japonya'da varllğını sürdürmekte olup, Amerika'nın getirdiği anayasa da hâlâ yürürlüktedir.

Amerika ile ittifak Japonya'ya hem avantaj hem de dezavantaj sağlamıştır. Öncelikle ittifak Japonya'ya gerekli olan askeri savunmayı sağlamıştır. Çünkü işgal döneminde Japonya tamamen silahsızlandırılmıştı. Güvenlik Antlaşması imzalandığında ise Japonya sadece yetmiş beş bin polis gücüne sahipti. Dolayısıyla ülkeyi koruyacak silahlı kuvvetler yeterli değildi. ${ }^{49}$ Ancak antlaşma gereği Amerikalılara Japonya'da askeri üs bulundurma hakkı tanınmıştı. Yani Amerikan birlikleri Japonya'ya yönelik herhangi bir saldırı anında ülkeyi korumakla görevlendirilebileceklerdi. Ayrıca ittifak sayesinde Japonya, Amerika'nın dış yardımlarına ve pazarına daha kolay ulaşabilecekti. Bu da Japonya'nın ekonomik anlamda kalkınması demekti. Ancak Japonya bir taraftan ekonomik olarak kalkınırken, diğer taraftan diplomatik anlamda Amerika'ya bağımlı oluyordu. Savaş sonrası dönemde Japonya diş politikasında özgürce hareket edememiş, Amerika'nın dış politikası güdümünde hareket etmeye mecbur bırakılmışt1. ${ }^{50}$ Dolayısıyla Japonya'nın Bandung Konferansı'na Amerika'nın etkisi olmadan katıldığını söylemek de pek mümkün değildir.

\section{Bandung Konferansı'na Japonya'nın Davet Edilmesi}

II. Dünya Savaşı'nda yaşananlardan sonra Japonya, Asya ile ilişkilerini yeniden kurma noktasında Çin ve Kore'den ziyade Güneydoğu Asya ülkeleri ile başlamayı tercih etmiştir. Bu doğrultuda Japonya, Güneydoğu Asya Bölgesi'ne geri dönme çabalarına tazminat görüşmeleri ile başlamıştır. ${ }^{51}$ Ancak görüşmeler pek istenildiği gibi gitmemiş̧ir. Savaş sonrası Japonya'nın Güneydoğu Asya ülkeleri ile ilk toplantısı olma özelliğine sahip Bandung Konferansı, hem tazminat sorununun çözümü hem de ilişkilerin düzeltilmesi anlamında ciddi bir başlangıç olmuştur. Japonya, Bandung'ta yeni doğan Asya ile ilk kez karşılaşmışıır. Aynı zamanda bağımsız bir statüye sahip Japonya'nın savaştan sonra katıldığı ilk uluslararası konferanstır. Bu nedenle Japon kamuoyu Bandung'a büyük ilgi göstermiştir. ${ }^{52}$ Ancak başlangıçta Japonya konferansa davet edilmek istenmemiş, Hindistan'ın konferansa davet edilecek ülkeler listesinde bu ülkenin adı yer almamıştır. Hindistan Başbakanı Jawaharlal Nehru, geçmişteki yayılmacı

\footnotetext{
48 Ancak antlaşmanın içeriği kendilerini tatmin etmediğinden Sovyetler Birliği, Polonya ve Çekoslovakya imzalamamışlardır. Bkz: Gönen 2007, s. 84.

${ }^{49}$ Huffman 2015, s. 129.

${ }^{50}$ Gönen 2013, s. 268.

${ }^{51}$ Hagiaki 2005, s. 188.

52 Taizō 2017, s. 70.
} 
politikası göz önüne alındığında bazı ülkelerin Japonya ile ilgili hâlâ endişeleri olduğunu ileri sürerek bu ülkenin katılmasına karşı çıkmıştır. Aslında Nehru'nun endişesi yersiz sayılmazdı. Çünkü Güneydoğu Asya ülkelerinin birçoğu 8 Eylül 1951'de imzalanan San Fransisko Barış Antlaşması'na katılmamışıtır. Bu durum tazminat sorunları ile ilgili yaşanan memnuniyetsizlikten kaynaklanmıştır. Bundan dolayı savaş sonrası süreç ikili müzakerelere bırakılmış, Japonya Filipinler, Endonezya, Burma ve Güney Vietnam'la tazminat görüşmeleri düzenlemiştir. Ancak daha önce de değindiğimiz üzere bu görüşmeler Japonya için pek de olumlu geçmemiş̧ir. Burma ile tazminat sözleşmesinin ve barış antlaşmasının imzaları, Bandung Konferansı'ndan önce 5 Kasım 1954 tarihinde tamamlanmıştır. Antlaşmaya göre Japonya, tazminatı ve ekonomik anlamda iş birliğini kabul etmiş̧tir. ${ }^{53}$ Ancak Endonezya ve Filipinler, savaş tazminatı ile ilgili görüşmeleri zora koşmuşlardır. İki ülkenin istediği ile Japonya'nın önerdiği oran arasında fark olunca sorun çıkmıştır. Bundan dolayı görüş̧meleri sonlandırmak biraz vakit almıştır. 1950’li yılların sonlarında başlayan görüşmelerin Burma'yla 1954, Filipinler'le 1956, Endonezya'yla 1958, Güney Vietnam ile 1959 yllı olmak üzere birbiri ardına sonuca bağlandığı görülmektedir. Ancak tazminat nakit olarak ödenmemiş, ürün ve hizmet sağlanması şeklinde olmasına karar verilmiştir. ${ }^{54}$

Pakistan Başbakanı Ali Butto (1928-1979) ise Japonya'nın Bandung'a davet edilmesi konusunda 1srarcı olmuştur. Jawaharlal Nehru'nun Japonya'yı istememesi gibi Pakistan Başbakanı Ali Butto ${ }^{55}$ da Çin'in davet edilmesini pek sıcak karşslamamışıtır. Butto'ya göre, Çin de sorun teşkil etmekteydi. Bununla ilgili Jawaharlal Nehru'ya "Ĕger bir endişeniz varsa Çin Komünist Patisi ne olacak?” diye sormuştur. Pakistan'ın ısrarını gören Jawaharlal Nehru, Japonya'nın davet edilmesine karşı çıkmaya devam ederse Çin'in davetinin zorlaşacağının farkına varmıştır. Bundan dolayı Japonya'ya yönelik tavrını değiştirmiş ve bu ülkenin de davet edilmesine karar vermiş̧tir. Peki, Pakistan niçin Japonya'nın davet edilmesi konusunda bu kadar ısrarcı olmuştur? Bu sorunun cevabı için bölgedeki Çin ve Hindistan etkisi ile Hindistan ve Pakistan arasındaki husumete bakmak yeterli olacaktır. Pakistan, Hindistan Dışişleri Bakanlı̆̆ı'nın politikasının Pakistan'ı yok etmek olduğunu düşünüyordu. Dolayısıyla Ali Butto, Bandung Konferansı'nın Hindistan ve Çin tarafından yönetilmesini ve bu iki ülkenin birleşerek Asya'daki girişimlerinin güçlenmesini, Asya'nın liderleri olmalarını ne olursa olsun durdurmaya çalışıyordu. Çünkü Güneydoğu Asya'da Çin ve Hindistan etkisi geçmiş̧e çok fazlaydı ve gelecekte de böyle olsun istemiyordu. Elbette Pakistan'ın bunu başarabilmesi için en önemli yöntemi, toplantıya Japonya'nın da davet edilmesini sağlamasıydı. Pakistan Japonya'nın komünizm karşıtı olduğunu biliyordu. Eğer Japonya konferansa katılırsa toplantının tek yöne yönlendirilmesini önleyebilir, Çin ile denge kurulabilirdi. Kısacası Pakistan'ın Japonya'yı davet etmek istemesi kesinlikle siyasi amaçlıyd. ${ }^{56}$

Bandung Konferansı için davetiye ulaştığında Japonya'da Yoshida Shigeru dönemi sona ermiş, ülkede siyasi anlamda değişim yaşanmaktaydı. Seçimlerden

\footnotetext{
${ }^{53}$ Steinberg 1990, s. 55.

54 Taizō 2017, s. 67-69.

55 Pakistan'ın yanı sıra Sri Lanka da Çin'in davet edilmesini istememiştir.

56 Taizō 2017, s. 43.
} 


\section{Emine SICIM KAPLAN}

Hatoyama Ichirō ${ }^{57}$ (1883-1959) galibiyetle ayrılmıştı. Yoshida Asya ülkeleri, özellikle Güneydoğu Asya bölgesiyle aralarındaki dış ticareti artırarak ekonomik anlamda karşılıklı ilişkileri güçlendirmek istemiş̧tir. Kendisi yönetimi boyunca Güneydoğu Asya ile dostane ilişkiler kurmaya, bölgeyle iş birliği içerisinde olmaya önem vermiş̧tir. Yoshida'dan sonra seçilen Hatoyama da Japonya'nın Asya ülkeleriyle olan ilişkilerini düzeltmesi ve geliştirmesi konusuna önem vermiştir.

Japonya'ya Bandung Konferansı ile ilgili davet mektubu da 15 Ocak $1955^{\prime}$ te Hatoyama döneminde ulaşmıştır. Geçmişte Asya-Pasifik bölgesini işgal eden Japonya için Bandung'a katılımı, savaştan sonra Asya'ya yeniden dönmesi demekti. Ancak Bandung'a heyet göndererek başta Amerika olmak üzere Batıli ülkeler ve Asya ülkeleriyle arasındaki ilişkilerini nasıl dengeleneceği konusu ilk kez gündeme gelmişti. Çünkü bu konferansa Çin ve Hindistan gibi Amerika'nın Soğuk Savaş politikasını eleştiren ülkeler de katıliyordu. Dolayısıyla bu ülkeler toplantıda Amerika'yı eleştirirse, Japonya'nın bu eleştirilere nasıl tepki vereceği sorun teşkil ediyordu. ${ }^{58}$ Ayrıca bu dönemde Japonya ile Amerika arasında 1954 krizi denen bir kriz vardı ve Japonya'da Amerika karşııı milliyetçilik oldukça artmış, Amerika'dan ayrılıp Çin ve Sovyetler Birliğine sıcak bakan, özellikle Çin ile ilişkileri ticari anlamda yeniden başlatmayı isteyenlerin sayısı da artmışıtı. Başbakan Hatoyama ve Dışişleri Bakanı Shigemitsu, Japonya-Amerika Güvenlik Antlaşması'nı feshetmeyi düşünmeseler de iki ülke arasında daha eşit bir ilişki arayışı içine girmişlerdi. ${ }^{59}$ Dolayısıyla Japonya, öncelikle Çin'in de katıldığı böyle bir toplantıya Batı bloğundaki ülkelerin, özellikle Amerika'nın tepkisini anlamanın doğru olacağına karar verdi. Bu doğrultuda Dışş̧leri Bakanlığı danışmanı Masayuki Tani ${ }^{60}$ (1889-1962) ve Japonya'nın Amerika Büyükelçisi Sadao Iguchi ${ }^{61}$ (1899-1980), Amerika tarafıyla temasa geçti. ${ }^{62}$ Savaştan sonra Japonya'nın Asya'dan bağımsız olduğunun farkında olan Amerika, bu ülkeye yönelik politikası konusunda ihtiyatlı davranıyordu. Dolayısıyla Amerika'nın Japonya'dan toplantıya katılmaması doğrultusunda bir talebi olmazdı. Eğer öyle bir talebi olsa bile Amerika, Japonya'yı kendi istekleri doğrultusunda hareket ettirdiği için sert eleştirilere maruz kalabilirdi. Bu durumu da istemeyen Amerika, Japonya'nın Bandung'a katılması konusunda olumsuz görüşte bulunmamıştır. Ancak Japonya'nın toplantıda komünizme karşı aktif rol alması konusunda beklentileri olmuştur. ${ }^{63}$ Dolayısıyla Japonya, Amerika'dan olumlu yanıtı aldıktan sonra Endonezya'ya konferansa katılacağını resmi olarak bildirmiştir. ${ }^{64}$

Japonya daveti kabul ettiğini 14 Şubat'ta bildirmiştir. 16 Mart 1955 'te yolladığ mektupla Endonezya, konferansa katılacak delegelerin isimlerini, biyografilerini, güncel

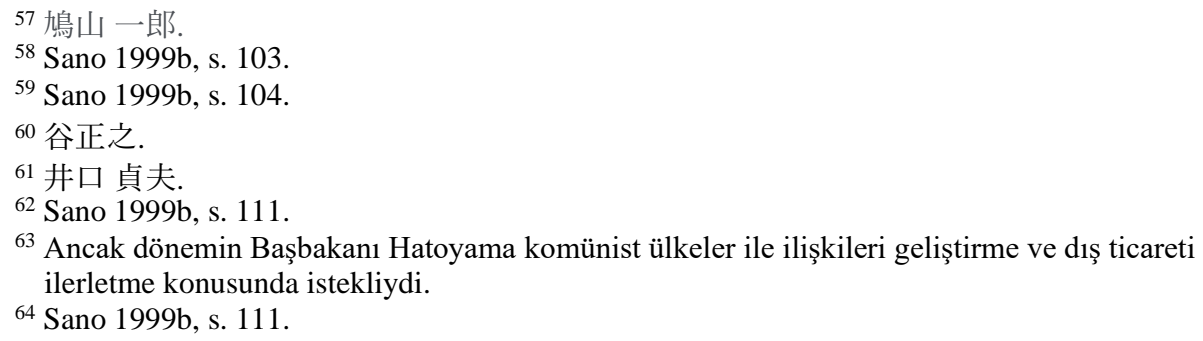


adreslerini ve fotoğraflarını mümkün olan en kısa zamanda kendilerine bildirmelerini istemiştir. ${ }^{65} \mathrm{Bu}$ bilgilerle delegelerin sadece konferansta değil, aynı zamanda konferans bittikten sonra iletişimde kalmalarına da yardımcı olacağını düşünmüşlerdir. Endonezya'dan gelen mektup üzerine Japonya, 1 Nisan 1955 'te baş delege olarak Takasaki Tatsunosuke' $\operatorname{nin}^{66}(1885-1964)$ katılmasina ve onunla birlikte otuz bir kişilik heyetin gönderilmesine karar vermiştir. Japonya, kişiler ve uçuşları hakkındaki ayrıntılı bilgiyi 8 Nisan 1955 tarihinde Endonezya'ya bildirmiştir. ${ }^{67}$ Buna göre Japonya heyeti 15 Nisan saat 20:00'de Tokyo'dan hareket edecek, ertesi gün saat 10:00'da Cakarta'ya varmış olacaklardı. Tokyo'dan hareket Endonezya'nın talebi doğrultusunda planlanmıştır. Çünkü Endonezya, Japon yetkililere delegelerin 17 Nisan'da Cakarta'da olmalarını isteyen bir mektup daha göndermiştir. Planlanan doğrultuda Japon heyet Bandung'a ulaşmıştır. ${ }^{68}$

\section{Bandung Konferansı ve Japonya'nın Rolü}

Bandung Konferansı'nda Japonya daha çok toplumsal ve ekonomik konular üzerinde durmuştur. 20 Nisan'daki sabah oturumunda Japonya, ekonomik kalkınma ve ticaretin gelişmesinde iş birliği yapacakların belirtmiştir. Bununla ilgili olarak da bölgelerde hızlı sanayileşme için eğitim merkezlerinin kullanılmasını veya yeni merkezlerin kurulmasını önermiş̧ir. Kendilerinin, teknik anlamda bilgi birikiminin oluşturulması, teknik eğitimin verilmesi ve şubelerin kurulması gibi konularda mevcut bulunan tesislere yardımcı olmaktan mutluluk duyacaklarını ifade etmişlerdir. $\mathrm{Bu}$ doğrultuda diğer ülkelere teknik uzmanlar ve kalifiye personel sağlamaya hazır olduklarını da eklemişlerdir. Aynı gün öğleden sonra düzenlenen oturumda Japonya Yakın ve Orta Doğu ile Afrika'yı kapsayan bölgesel bir ekonomik organizasyon kurulmasını desteklemiştir. ${ }^{69}$ Bununla ilgili olarak ertesi gün düzenlenen sabahki oturumda Japonya şu şekilde ifade etmiştir:

"Biz Asya-Afrika bölgesindeki ekonomik sorunlar ile ilgili bir organizasyon kurulması fikrini destekliyoruz. Bununla birlikte, bu örgütün çalışmalarının, Asya ve Uzakdoğu için Birleşmiş Milletler Ekonomik Komisyonu gibi uluslararası kuruluşlarla koordinasyon içinde yürütülmesine gereken özen gösterilmelidir. Bu bağlamda, ilgili ülkelerin temsilcilerinin zaman zaman bir araya gelerek bilgi alışverişinde bulunabileceği veya kendi ekonomik programlarını koordine edebileceği bir danışma komitesinin kurulması faydalı olacakttr. "’0

Aynı oturumda (21 Nisan sabah saatinde düzenlenen) Japonya, II. Dünya Savaşı'nda yok olan filolarını yeniden inşa ettiklerini, bu doğrultuda gemilerinin bölgede bulunan ülkeler lehine kullanılmasını memnuniyetle karşılayacaklarını dile getirmiştir. Okyanusa giden gemilerden ayrı olarak, kıyı taşımacılığında küçük gemilerin daha

\footnotetext{
${ }^{65}$ B20010350900, 1955.03.02 - 1955.04.24, Belge No: 394/ VIII.

66 高碕達之助.

${ }^{67}$ B20010350900, 1955.03.02 - 1955.04.24, Belge No: 34/A1.

${ }^{68}$ B20010350900, 1955.03.02 - 1955.04.24, Belge No: 20349 JS/25.

${ }^{69} \mathrm{~B} 20010362500,1955.4 .22$, s. 12.

${ }^{70}$ B20010362600, 1955.4.22, s. 66.
} 
önemli olduğunu vurgulayıp, bölgedeki birçok ülkenin küçük gemilerini güçlendirmeleri gerektiğini ve ekonomik gelişme için en önemli işlerden birinin de bu olduğunu ifade etmiştir. Japonya'nın bu tarz gemileri inşa etme kapasitesine sahip olduğundan, iş birliği yapabileceklerini de eklemiştir. Ayrıca Japonya toplantıda, bölgeden ucuza petrol ithal etmek istediklerini de dile getirmiştir. Geçen yıl iki yüz milyon dolarlık petrol ithal ettiklerini, bu ithâlâtın büyük bir kısmı tedarik kaynaklarına kaydırılabilirse bölgedeki ülkeler ile kendileri arasındaki ticaretin artabileceğini belirterek bölgeden ucuza petrol ithal etmek istediklerini vurgulamıştır. ${ }^{71}$

Konferansta Japonya, ekonomik ve toplumsal konularda aktif rol oynarken, siyasi konularda daha pasif davranmış, komünizm karşıtı bir tavır sergilemekten kaçınmıştır. Bunun sebebini şöyle açıklamak mümkündür: Amerika, Japon heyetin kendisinin soğuk savaş siyasetini destekleyip, Bandung’ta komünizme karşı aktif rol oynamasını beklemişti. Ancak daha önce de belirttiğimiz üzere bu konferans savaştan sonra Japonya'nın yeniden Asya’ya dönmesiydi. Dolayısıyla Japonya'nın komünizme karşı çıkmak için aktif rol sergilemesi, savaştan önceki işgalci Japonya'yla ilişkilendirilebilirdi. $\mathrm{Bu}$ durum da Japonya'nın Asya ülkeleri ile dostane ilişkiler kurmasına engel olabilir, bu ülkelerle kuracağı ticari ilişkileri de zarar verebilirdi. Bundan dolayı Japonya, Asyalı ülkelerin kendisine yönelik şüpheci tavırlarını yumuşatmak için konferansta siyasi konuların tartışılmasında aktif rol almaktan kaçınarak, yalnızca uluslararası çatışmaların barışçıl yollarla çözülmesini isteyen Bandung Barış Bildirgesi’ni önermiştir. ${ }^{72}$ Toplantıda beş barış ilkesi ${ }^{73}$ yerine Birleşmiş Milletler Antlaşması'na saygı duyulması gerektiğini savunmuş, Birlemiş Milletler ile iş birliği yapıp, dünya barışını desteklemekte kararlı olduklarını vurgulamıştır. ${ }^{74} 21$ Nisan'daki toplantıda Japonya, barış ile ilgili düşüncelerini açıklarken, atom ve hidrojen bombasının korkunçluğu hakkında konuşacak, bu bombaların güçlerinin barışçıl kullanımını savunabilecek en tecrübeli ülkenin kendileri olduğunu belirtmiştir. Devamında:

“Japonya iki kez atom bombasının düşü̈̆ü ilk ülkedir ve umut ederim ki son ülke olur. Ne yazık ki Japonya, hidrojen bombasından etkilenen de ilk ülkedir. Nükleer enerjinin barışçl amaçlarla kullanılmasının, insan toplumunu sanayi devrimine kıyasla daha fazla kökten değiştirmesi beklenmektedir. Günümüzde nükleer enerjinin barlşçıl amaçlarla kullanılmasılla ilgili bazı sorunlar mevcuttur. Öncelikle nükleer enerji ilk kez kullanıldı̆̆ında yok etmek amacıyla kullanılmıştır. Şimdi bile savaşla sınırlandırılmıştır. Ayrica nükleer enerjinin istismart ile ilgili teknik bilgi birkaç büyük ulusun tekelindedir. Japonya'nın dileği, nükleer enerjinin geliștirilmesinin ve kullanımının sadece doğrudan insan refahını sağlanmak için olması yönündedir. Ülkemiz nükleer enerjinin barışçıl

\footnotetext{
${ }^{71}$ B20010362500, 1955.4.22, s. 12, 15-16.

${ }^{72}$ Sano 1999b, s. 103.

${ }^{73}$ Katılımcılar, Budizm'in beş ilkesi olan Pancha Shila'yla benzer ilkeleri konferans sonunda dile getirmişlerdir. Buna göre bu beş ilke; toprak bütünlüğü ve egemenliğe saygı, saldırmama ve içişlerine karışmama, eşitlik, karşılıklı kazanç ve barış içinde birlikte yaşama, her ülkenin kendi kaderini şekillendirmesidir. Bandung Konferansı'nda bu beş ilke on bölüme ayrılmış ve somutlaştırılmıştır. Bkz: Rao 1955, s. 320.

${ }^{74}$ Taizō 2017, s. 51.
} 


\section{Özgürlük Yolu: Bandung Konferansl ve Japonya}

kullanımını teşvik etmek için uluslararası iş birliği çabalarına tam anlamıyla katılmaya hazırdır." ${ }^{, 5}$

Alıntılanan kısımdan da anlaşılacağı üzere Japonya, bundan sonra niyetinin barışa hizmet etmek olduğunu, geçmişin aksine kendisini barışa adamış bir ulus olarak yeniden doğduğunu göstermiştir. II. Dünya Savaşı'nda komşu ülkelerine zarar veren ve atom bombasının yıkımını yaşayan tek ülke olan Japonya'nın, kendini barışı adamış bir ulus olarak yeniden doğduğunu Takasaki'nin sözlerinden de anlamak mümkündür. Takasaki toplantıda şöyle bir konuşma yapmıştır:

“II. Dünya Savaşı'nda Japonya'nın komşu ülkelere zarar verdiğini söylemekten üzüntü duyuyorum, ancak bu durum tarifsiz actlarla sona erdi. Japonya, can ve mal açısından büyük bir bedel ödeyerek dersini aldl ve demokrasiyi yeniden kurdu. Bugün terbiyeli ve özgür, kendini tamamen barışa adamış bir millettir." "76

Takasaki konuşmasında Japonya'nın komşularına zarar verdiğini kabul etmiş ve özür dilemiş̧tir. Devamında da kendilerinin dünyada barışı sağlamak için olumlu anlamda katkılarda bulunacaklarını dile getirmiş, uluslararası sorunları çözmede yöntem olarak savaşı kullanmayı bıraktıklarını ilan etmiştir. Bu noktada Japon Anayasası'nın dokuzuncu maddesini hatırlatmakta fayda vardır. Bu maddeye göre Japon halkı savaş hakkından feragat ederek, uluslararası anlaşmazlıkları barış̧̧ı yollarla çözeceklerini beyan etmişlerdir. Son olarak Takasaki, bu konferansın Asya ve Afrika ülkeleri arasındaki karşılıklı anlayışı, dostluğu ve kültür alışverişini derinleştirmesini, Asya ile Afrika'nın yeniden inşası için iyi bir firsat olmasını umut ettiğini belirterek konuşmasını sonlandırmıştır. ${ }^{77}$

Konferans sonunda Jawaharlal Nehru, Japonya'nın yanlış temsilci gönderdiğine dair eleştiride bulunmuştur. Takasaki Tatsunosuke gibi ekonomi uzmanı birinin Japonya'yı siyasi açıdan temsil etmemesi gerektiğini savunmuştur. Dolayısıyla Japonya'nın toplantıya katkıda bulunamadığını ve bunun Japonya açısından üzücü bir durum olduğunu dile getirmiştir. ${ }^{78}$ Japonya konferansa katılan ülkeler içerisinde nispeten daha modern ve yüksek oranda sanayileşmişsir. Ancak savaş sonrası gelişmeler nedeniyle, hâlâ iç enflasyon ve dış ödemeler dengesizliği yaşadığı yadsınamaz bir gerçektir. Japonya açısından konferans etkili sonuçlanmasa da o dönemdeki Japonya'nın bölgeye yönelik öncelikli amacı siyasetten ziyade ekonomiktir. ${ }^{79}$ Bundan dolayı toplantiya ekonomi uzmanının gönderilmesi beklenen bir durumdur. Ancak bir noktada da Nehru'ya katılmak mümkündür. Takasaki'nin siyaset anlamında deneyimi çok fazla değildir. Nitekim kendisi de Bandung konferansı için hayatının dönüm noktası olduğunu belirtmiş, devamında da "Bandung Konferansı benim hayatımı değiștirdi. Siyasete yönelik ilgimi, diplomasiye yönelik ilgimi bu toplantı sayesinde kazandım. " 80 şeklinde dile getirmiş̧ir.

\footnotetext{
${ }^{75}$ B20010362600, 1955.4.22, s. 39-40.

${ }^{76}$ Wright 1956, s. 128-129.

${ }^{77}$ Sano 1999b, s. 122.

${ }^{78}$ Taizō 2017, s. 50.

${ }^{79}$ Er 1996, s. 41.

${ }^{80}$ Sano 1999b, s. 134.
} 
Bandung Konferansı'nda ekonomik konularda aktif rol sergileyen Japonya, kültür ile ilgili konularda da kendini göstermiştir. Bununla ilgili olarak Aiichirō Fujiyama ${ }^{81}$ (1897-1985), Asya Afrika Kültür Ödülü oluşturulmasını ve bölgenin kültürel gelişimini teşvik etmek için tasarlanmış en iyi çalışmanın veya performansın her yıl bu ödülle ödüllendirilmesini önermiştir. ${ }^{82}$ Aiichirō’nun önerisi büyük övgü toplamış, ancak finansal zorluklar nedeniyle kabul edilmemiştir.

Savaştan sonra Japonya Asya ülkeleri ile arasını düzeltme konusunda oldukça çaba harcamıştır. Ancak Japonya'nın uluslararası çevrede çok sıcak karşılanmadığı da bir gerçektir. Aynı şekilde Bandung Konferansı da Japonya için pek başarıı sonuçlanmamıştır. Buna rağmen konferansın karşlıklı ilişkileri düzeltme konusunda etkili olmadığı da söylenemez. Konferanstan sonra Japonya'nın bölge ile teması artmıştır. Asya'nın barışı ve refahı için ekonomik birlikteliği ve kültürel bağı desteklemek gerektiğine inanan Japonya Başbakanı Kishi Nobusuke ${ }^{83}$ (1896-1987), 1957 yılının Mayıs ve Haziran aylarında Burma, Hindistan, Pakistan, Sri Lanka, Tayland ve Tayvan'1 ziyaret etmiştir. Aynı yılın kasım ve aralık aylarında da Güney Vietnam, Kamboçya, Laos, Malezya, Singapur, Endonezya, Avustralya, Yeni Zelanda ve Filipinleri ziyaret etmiştir. ${ }^{84}$ $\mathrm{Bu}$ dönemde Japonya'nın güneydeki en önemli rotası Endonezya olmuştur. Başbakan Kishi, 1957 yılındaki Endonezya ziyaretinde tazminat görüşmelerinde mutabakatı sağlamış, ertesi yıl da dönemin Dışişleri Bakanı Aiichirō Fujiyama Endonezya'yı ziyaret edip, barış anlaşması ve tazminat paktı imzalamıştır. Bandung'tan sonra iki ülkenin ilişkilerinin derinleştirdiği görülmektedir. Japonya, sadece Endonezya'yla değil, Filipinler ve Güney Vietnam'la olan tazminat görüşmelerini de Bandung Konferansı'ndan kısa süre sonra tamamlamıştır. ${ }^{85}$

\section{SONUÇ}

Bandung Konferansı, Batı'yı endişelendiren ve Batı'nın söz sahibi olmadığı ilk uluslararası toplantıdır. Asya ve Afrika'da bulunan ülkelerin, Amerika Birleşik Devletleri, Sovyetler Birliği ve Batı Avrupa gibi büyük ülkelerin merkezinde bulunan uluslararası siyaset sahnesine çıkmasıdır. Aynı zamanda Bandung, Asya'nın yeniden doğuşunun ve Asya milliyetçiliğinin sembolüdür. Bu konferans, ülkeler arasında yeni bir siyasi uyanışın olduğunu ve ülkelerin kendi ayakları üzerinde durmak istediklerini göstermiş, Asya'da yeni bir dönemin başladığının kanıtı olmuştur. Asya ve Afrika ulusları arasındaki iş birliğinin gelişmesi açısından da önemli bir adım teşkil etmiştir. Toplantıda her bir ülkenin temsilcileri, konferansın önemi ve amacı ile ilgili açıklamalarda bulunmuşlar; siyasi sorunları, ırkçılığı ve sömürgeciliği tartışmışlar; bunun yanı sıra komite kurarak ekonomik birliktelik, kültür alışverişi gibi konuları da ele almışlardır. Bandung Konferansı'nın yüzde yüz başarılı sonuçlandığını, konferansta her soruna çözüm bulunduğunu söylemek elbette mümkün değildir. Ancak Bandung'un; sömürgeden

\footnotetext{
81 藤山 愛一郎.

${ }^{82}$ B20010362000, 1955.4.23, s. 93.

83 岸信介.

${ }^{84}$ Hagiaki 2005, s. 199.

${ }^{85}$ Taizō 2017, s. 83.
} 


\section{Özgürlük Yolu: Bandung Konferansl ve Japonya}

kurtulan ulusların yeni dünya düzeninde yer almak; kendi hayatlarında söz sahibi olmak; Batı'nın boyunduruğunda yaşamak değil, onlarla iş birliği içerisinde olmak ve saygı görmek, eşit sayılmak istediklerini gösterdikleri, kısacası şimdiye kadar göz ardı edilen Asyalı ve Afrikalı ulusların tek güç olarak seslerini duyurdukları bir platform olduğunu söyleyebiliriz. Özetle Bandung Konferansı, sömürge olmaktan kurtulmanın, özgürlük yolunun sembolüdür. Yıllarca sömürge altında yaşamış ulusların bağımsızlıklarını, kendileri gibi aynı kaderi paylaşanlarla tüm dünyaya ilan etme aracıdır. Artık her şeyin farklı olacağını, Asya ve Afrika döneminin başladığını simgeleyen tarihi bir olaydır.

Japonya için ise Bandung Konferansı, savaştan sonra katıldığı ilk uluslararası toplantı olma özelliği taşımaktadır. Konferansın düzenlendiği dönemlerde Japonya işgalden yeni çıkış ve Asya ülkeleriyle kötü olan ilişkilerini yeniden düzeltme konusunda çabalamaktadır. Bu toplantıda Japonya, yeni doğan Asya ile ilk kez karşılaşmış, Asya'ya yeniden dönme şansı yakalamıştır. Japonya, geçmişte yaşattıklarından dolayı Bandung'taki konumunun hassaslığının farkında olmuş ve konferansta tartışılan konulara yapıcı yaklaşmıştır. Asya'da barış ve istikrarın geliştirilmesine katkıda bulunma konusunda iş birliği yapacağını göstermiş, nükleer enerjinin barış için kullanılması gerektiğini vurgulamıştır. Özellikle, II. Dünya Savaşı'ndan can ve mal açısından büyük bir bedel ödeyerek dersini aldığını ve demokrasiyi yeniden kurduğunu dile getirerek, kendilerini tamamen barışa adamış birer millet olarak hareket edeceklerini vurgulamıştır. Asya ülkeleri ile dış ticareti artırmayı ve teknik anlamda kalifiye personel sağlamada hazır olduklarını belirtmiştir. Kısacası Japonya'nın Bandung Konferansı'na katılması, geçmişi geride bırakarak Asya bölgesi ile yeni ilişkiler kurmak; her anlamda bölgeye yardımcı olarak iş birliği yapmak ve bu sayede bölge ile sürekli iletişim halinde olmak istediğini göstermiştir.

Diğer taraftan Bandung Konferansı'nın Japonya açısından pek başarılı sonuçlanmadığını söylemek mümkündür. Her ne kadar toplantının uluslararası büyük güçlerden bağımsız olarak yapılmasına dikkat edilmişse de Japonya, Amerika'ya danışmadan konferans davetine olumlu yanıt verememiştir. Bundan dolayı işgalden yeni çıkan Japonya, Asyalı ülkelere geçmişte yaşattıklarını unutturmak ve Amerika ile Asya arasında denge sağlamak için konferansta ihtiyatlı davranmıştır. Bandung'ta toplumsal ve ekonomik konularda aktif rol sergilerken, siyasi konularda pasif davranmayı seçmiştir. Amerika'nın beklentilerinin aksine konferansta komünizm karşıtı olmak yerine, Asya'yla (Çin de dâhil olmak üzere) ilişkilerini düzeltmek ve ekonomik yollarla bölgede kendine yeniden yer edinmek için çabalamıştır. Dolayısıyla Bandung, Japonya'nın uluslararası ilişkilerde ve dış politikasında temkinli davrandığını göstermiştir. Ancak yine de Japonya'nın, Endonezya gibi bazı ülkelerle ikili ilişkilerini düzeltmesinde ve geliştirmesinde Bandung Konferansı'nın katkısını göz ardı etmemek gerekir. 


\section{KAYNAKLAR}

\section{1- Arşiv Belgeleri}

JACAR (Japan Center for Asian Historical Records) Ref. B20010362500, Report of the Economic Committee of Asian-African Conference, /分割 1, 1955.4.22.

JACAR (Japan Center for Asian Historical Records) Ref. B20010362600, Report of the Economic Committee of Asian-African Conference, / 分割 2, 1955.4.22.

JACAR (Japan Center for Asian Historical Records) Ref. B20010362000, AsianAfrican Conference,Meeting of the Heads of Delegations / (4) Proceedings of the Meeting of Heads of Delegations, 1955.4.23.

JACAR (Japan Center for Asian Historical Records) Ref. B20010350900, 人事関 係, ジャカルタアフロアジア会議合同事務局長, 1955.03.02 - 1955.04.24.

\section{2- Süreli Yayınlar}

Cairns Post ( https://trove.nla.gov.au/newspaper/article/42511985)

The Tibet Sun (https://web.archive.org/web/20110717053545)

Official Gazette (https://www.officialgazette.gov.ph/1950/05/26)

The Northam Advertiser (https://trove.nla.gov.au/newspaper/article/211941419)

\section{3-Kitap ve Makaleler}

Ahmed 1955

Apparodai 1955

Çakmak 2013

Dennehy 2011

Er 1996

Fitzgerald 1955

Gotō 2003

Gönen 2007

Gönen 2013
Mushtaq Ahmed, "Bandung Conference", Pakistan Horizon, 8 (2), s. 362-366.

A. Apparodai, "The Bandung Conference", India Quarterly, 11 (3), s. 207-235.

Haydar Çakmak, ABD'nin Askeri Madahaleleri (1801'den Günümüze), Kaynak Yayınları, İstanbul.

Kristine Dennehy, "The Bandung Conference, 1955”, Ed. Sven Saaler ve Christopher W. A. Szpilman, Pan-Asianism, A Documentary History 1920-Present, Rowman\&Littlefield, İngiltere, 2. Cilt, s. 299-307.

Lam Peng Er, “Japan's Search for a Political Role in Southeast Asia", Southeast Asian Affairs, s. 40-55.

C.P. Fitzgerald, "South-East Asia After Bandung", The Australian Quarterly, 27 (3), s. 9-17.

Ken'ichi Gotō, Tensions of Empire Japan and Southeast Asia in the Colonial \& Postcolonial World, Singapore University Press, Singapur.

Hakan Gönen, Modern Japonya'nın Ulusal Güvenlik Anlayışı, Alp Yayınevi, Ankara.

Hakan Gönen, “Japonya'nın ABD ile Güvenlik İttifakı Boyutundan Orta Doğu Politikası", Ed. Mete Tunçoku, Japon Dış Politikası, Nobel Yayıncılık, Ankara, s. 263 - 285. 
Hagiaki 2005

Holcombe 2017

Huffman 2015

Lu 1996

Murat 2018

Prashad 2007

Purcell 1965

Rakove 2018

Rao 1955

Redding 1956

Sano 1999a

Sano 1999b

Shimazu 2014

Steinberg 1990

Stockwell 2008

Taizō 2017

Wright 1956
Yoshiyuki Hagiaki, “戦後日本の南方回帰”, Ed. Yano Tooru, 東 南アジアと日本, 10. cilt, Kōbundō, Tokyo, s. 187-204. Charles Holcombe, A History of East Asia From the Origins of the Civilization to the Twenty - First Century, Cambridge University Press, İngiltere.

James L. Huffman, Japonya Tarihi, Çev. Cengiz Yücel, İnkilap Kitabevi, İstanbul.

David J. Lu, Japan: A Documentary History: Vol 2: The Late Tokugawa Period to the Present, Routlegde, Londra.

Turgay Murat, "Bandung Konferansı ve Türkiye", Firat Üniversitesi Sosyal Bilimler Dergisi, 28 (2), s. 363 - 379.

Vijay Parshad, The Darker Nations A People's History of the Third World, The New Press, New York.

Victor Purcell, South and East Asia Since 1800, Cambridge University Press, Londra.

Robert B. Rakove, "Bandung Conference (1955)", The Encyclopedia of Diplomacy, s. 1-4.

V. Venakata Rao, "The Asian-African Conference", The Indian Journal of Political Science, 16 (4), s. 312-324.

Saunders Redding, "The Meaning of Bandung", The American Scholar, 25 (4), s. 411-420.

Masafumi Sano, “バンドン会議とアメリカ : 戦後アジア国際関 係の新展開という文脈の下で”, 史学研究会, 82(1), s. $122-143$. Masafumi Sano, “バンドン会議と鳩山内閣”, 史林, 82(5), s. 770806.

Naoko Shimazu, "Diplomacy As Theatre: Staging the Bandung Conference of 1955", Modern Asian Studies, 48 (1), s. 225-252. David I. Steinberg, "Japanese Economic Assistance to Burma: Aid in the "Tarenagashi" Manner?", Crossroads: An Interdisciplinary Journal of Southeast Asian Studies, 5(2), s. 51 $-107$.

A.J. Stockwell, "Southeast Asia in War and Peace: The End of European Colonial Empires", Ed. Nicholar Tarling, The Cambridge History of Southeast Asia, 2. cilt, Cambridge University Press, İngiltere, s. 325 - 387.

Miyagi Taizō, 増補海洋国家日本の戦後史, Chikuma, Tokyo. Richard Wright, The Colour Curtain A Report on The Bandung Conference, Dobson Books, Londra.

\section{4-İnternet Kaynakları}

http://asianafricanmuseum.org/en/gedung-merdeka-dari-masa-ke-masa/, 22.11.2021 tarihinde ulaşılmıştır. 


\section{SUMMARY}

The end of the Second World War was the beginning of a new era for Southeast Asia. Because Southeast Asian nations colonized by Western power for years and after war they started to fight for freedom. While the countries in the Southeast Asian region were fighting for freedom, Japan occupied by American about seven years from 1945 to 1952. After a long struggle, most of the countries in Southeast Asia became independent. These countries, which have recently gained their independence, decided to organize the Bandung Conference. Bandung Conference, also known as the Asian-African Conference, organized by Indonesia, Myanmar, Sri Lanka, India and Pakistan, which took place April 18-24, 1955, in Bandung, Indonesia. Bandung Conference was the first Asia-Africa conference and also not attended by Western powers in history. Representatives from twenty-nine governments of Africa, Asia, and the Middle East nations, including Japan, Egypt, Indonesia, India, Iraq, and the People's Republic of China etc attended the conference. The countries met in order to develop their mutual relations in line with their common interests and consider the issues they considered most pressing. Also they met to discuss peace and economic development, condemn colonialism, decry racism.

In the beginning, Japan was not asked to be invited to the conference due to the past experiences. The name of Japan was not included in the list of countries to be invited to the conference. Jawaharlal Nehru, first prime minister of independent India, argued that some countries still have concerns about Japan due to its past expansionist policy and he opposed to Japan's participation. On the other hand, Ali Bhutto, who was the Prime Minister of Pakistan, insisted on inviting Japan to Bandung. And in the end, the Japan was invited. When the invitation for the Bandung Conference was received, in Japan the Yoshida Shigeru's period ended and Hatoyama Ichirō elected Prime Minister and his period began. Hatoyama decided to attend the Bandung Conference. Japan dispatched its Minister of State and Chief of the Economic Deliberative Agency Takasaki Tatsunosuke. The Bandung Conference was the first major international conference that Japan, with an independent status, attended after the Second World War. In this meeting, Japan met the newborn Asia for the first time and had the chance to gain readmission into Asia. Japan became aware of the sensitivity of its position in Bandung due to its past experiences and approached the issues discussed at the conference constructively.

At the Bandung Conference, Japan focused on social and economic issues rather than political issues. Japan recommended measures to improve and expand the trade. At conference Japan advocated that in order to expand the trade among Asian - African countries and to raise their level of consumption, efforts must be made to stigulate new demands. According to Japan, some of the measures to promote such a developmet were the holding of trade fairs, the exchange of samples though simplified customs procedures and regulation and the interchange of trade information among countries in the AsianAfrican region. Japan supported the idea of establishing an organization to deal with the economic problems of the Asian-African region. Japan stated that due attention should however be paid in conducting the work of this organisation in coordination with 
international bodies, such as the United Nations Economic Comission for Asia and the Far East. Also Japan advocated that it would be useful a Consultative Committee, where the representatives of the countries concerned, may meet from time to time exchange information or coordinate their respective economic programmes. Besides, Japan offered an idea to establish a regional economic organisation covering Near and Middle East and Africa.

On the other hand, Japan has not only talked about economic issues, but also told about peace at the conference. About this, the Japanese Delegate advocated that Japan was the best example to speak about the horror of the Atom Bomb and to assert for the peaceful use of the formidable power of the Atom and Hydrogen. Because Japan was the first country where two Atom Bombs had been dropped. Japan was also the first country again which suffered from the Hydrogen Bomb. So according to Japan, if nucleer energy used of peacufel purposes, it would bring about human welfare. Therefore, Japan advocated to the development and use of nuclear for peace. Also Japan declared its readiness to participate on a full scale in the efforts of international cooperation to promote the peaceful use of nuclear energy. At the Bandung Conference, Japan also gave its views culturally. In relation to this, he proposed the establishment of the Asia Africa Cultural Prize to be awarded annually to the best work or performance designed to promote the cultural advancement of the region. 